\title{
School Climate in Highly Effective Schools in the Autonomous Region of the Basque Country (Spain)
}

\author{
Clima Escolar en los Centros Escolares de Alta Eficacia de la \\ Comunidad Autónoma del País Vasco (España)
}

\author{
Feli Etxeberria * \\ Nahia Intxausti \\ Verónica Azpillaga
}

Universidad del País Vasco/Euskal Herriko Unibertsitatea

\begin{abstract}
This study, part of a wider study, presents the results concerning school climate as examples of best practices in highly effective schools. Thirty-two primary and secondary schools were identified and selected using multilevel statistical modelling techniques and hierarchical linear models that identified schools with higher-than-expected student results from among all the schools in the Autonomous Region of the Basque Country. Once schools had been identified and characterised, the best practices were selected via a qualitative study involving 83 interviews with 3 groups of key informants: 25 inspectors, 26 educational advisors and 30 management teams from the 32 selected schools. Results show that school climate incorporates aspects related to academic climate, social relations and organisational structure. The development of school climate is linked to teachers' commitment to educational work, involvement, teamwork and participatory management. The ultimate aim of this study is for the best practices identified to serve as a useful tool in the design and implementation of the improvement actions carried out in all schools in the Spanish Autonomous Region of the Basque Country. Thus, one suggestion is to broaden our understanding of climate beyond peaceful coexistence between students, and to include teamwork processes and democratic participation in the peaceful coexistence plan.
\end{abstract}

Keywords: School discipline, Educational innovation, Educational efficiency, Primary education, Secondary education.

Este trabajo, fruto de una investigación más amplia, trata de dar a conocer que el clima escolar forma parte de las buenas prácticas de los centros escolares de alta eficacia. Se han identificado y seleccionado a través de técnicas estadísticas multinivel y modelos jerárquicos lineales 32 centros de alta eficacia entre todos los centros de la Comunidad Autónoma Vasca. La caracterización de sus prácticas se ha realizado con metodología cualitativa, a través de cabo ochenta y tres entrevistas a tres colectivos de informantes clave: 25 inspectores e inspectoras de referencia; 26 asesores de referencia y 30 equipos directivos de los 32 centros seleccionados. Dan a conocer que la dimensión clima escolar en estos centros incorpora aspectos relacionados con el clima académico, relación social y estructura organizativa. El desarrollo del clima del centro va unido a la implicación del profesorado en la labor educativa, trabajo en equipo y la gestión participativa. El objetivo último de este estudio es que las buenas prácticas identificadas sirvan como herramientas para diseñar e implementar acciones de mejora en los centros de la Comunidad Autónoma del País Vasco. Así, entre las sugerencias se propone ampliar la perspectiva del clima más allá de la convivencia entre el alumnado, e incorporar procesos de trabajo en grupo y la participación democrática en el plan de convivencia.

Descriptores: Disciplina escolar, Innovación educacional, Eficiencia de la educación, Enseñanza primaria, Enseñanza secundaria.

*Contacto: feli.etxeberria@ehu.eus

ISSN: $1696-4713$

www.rinace.net/reice/

revistas.uam.es/reice
Recibido: $\quad 15$ de junio 2017

$1^{\text {a }}$ Evaluación: 3 de agosto 2017

$2^{\text {a }}$ Evaluación: 21 de agosto 2017

Aceptado: $\quad 28$ de agosto 2017 


\section{Introduction}

This research project, entitled "Characterisation and best practices in high added value schools in the Autonomous Region of the Basque Country (ARBC)" aims to identify highly effective schools and compile a catalogue of the best practices employed by them. A total of 32 highly effective schools were selected, with an even split between primary and secondary. The criterion for selection was that schools must have obtained higherthan-expected student results after adjusting for the effect of contextual variables using multilevel statistical modelling techniques (Lizasoain et al., 2012). The findings of the first phase of the research project indicate that fostering a good school climate is one of the best practices employed in these schools.

\section{Theorical framework}

\subsection{School effectiveness}

The project is located within the approach known as Effective School Improvement, which aims to link the contributions of the theoretical school effectiveness movement with those of the practical school improvement movement. From this perspective, the study aims to identify highly effective schools in order to compile a catalogue of best practices. This catalogue will serve as a useful tool in the design and implementation of the improvement actions and programmes that all schools in the Spanish Autonomous Region of the Basque Country (ARBC) are obliged to establish.

The first person to begin researching school effectiveness was Weber (1971), who demonstrated the impact of schools on students' academic performance. He used the case study method to analyse schools which managed to encourage students to learn more than was expected given their particular context. This broke away from the tradition of emphasising the psychological perspective, and opened up a new field of research which took process factors into consideration. This in turn gave rise to the use of the inputprocess-product (IPP) methodological model instead of the previously-employed inputoutput model, which focused solely on the relationship between the school's input elements and student results in terms of achievement.

Initially, the research movement into school effectiveness lacked any empirically validated theoretical framework. Aware of this lack, authors' response was to develop a comprehensive theory of the factors that intervene in an effective school (Reynolds et al., 2005; Townsend, 2007).

Edmonds (1979) developed a five-factor model of effectiveness based on studies conducted in the United States. The five factors were: leadership, high expectations, school climate, focus on work and student assessment and monitoring. Based on the works published by Brookover and others (1979) and Rutter and others (1979), other authors began using qualitative techniques in the methodological field to study processes in both the school itself and the classroom (Purkey \& Smith, 1983).

During the same decade, the movement entered a new methodological phase, more focused on statistics and using multi-level hierarchical models. This is turn gave rise to an analysis of school effectiveness at different levels, within a context-input-processproduct approach. The aim was to develop comprehensive school effectiveness models. 
One example of this is the integrated school effectiveness model developed by Scheerens (1990). This model contains a systemic structure of variables organised in accordance with context, input, process (at the level of both school and classroom) and product. The hierarchical model of school effects proposed by Stringfield and Slavin (1992) also has four levels: student, classroom, school and context. And soon after, Creemers (1994) proposed a school effectiveness model with, again, four levels of analysis: student, classroom, school and context, and included the components quality, time and opportunity in each. These proposals for comprehensive school effectiveness models all share a set of basic characteristics, namely they are all based on a systemic view of the school environment and include four levels of analysis.

Over recent decades, studies have focused on the identification of the school, classroom and context factors associated not only with academic performance but also with students' all-round development (Gray, 2006; Hernández-Castilla, Murillo, \& MartínezGarrido, 2014; Murillo \& Hernández-Castilla, 2011). These studies adopt a view of effectiveness which includes students' all-round education and development.

\subsection{School climate in school effectiveness models}

Research carried out into effective schools has identified school climate as an important variable. The following are some of the studies which have focused on climate within the field of school effectiveness.

Purkey and Smith (1983) state that an orderly school climate is a process variable that entails having clear, reasonable and consistently-enforced rules. Sammons, Hilman and Mortimore (1995) list eleven factors for an effective school which include a learning environment with a calm, orderly atmosphere, and an agreeable, attractive physical environment which facilitates students' work. They also highlight the importance of positive reinforcement with a clear, fair, disciplinary model based on recognition and appreciation.

Just like Creemers' model (1994), Scheerens' integrated school effectiveness model (1992) includes an orderly and safe environment and discipline as process factors at the school level. Other authors have also pointed out that effective schools have an orderly, safe and disciplined climate (Scheerens \& Bosker 1997; Scheerens et al., 2013).

Other studies allude to the importance of focusing on learning achievements, monitoring students' work and helping them remain focused on learning the skills to be acquired. Stoll and Fink's model (1999) establishes three groups of factors associated with school effectiveness. Of special interest here, in relation to climate, is ensuring a stimulating learning environment which includes student engagement, physical surroundings, acknowledgment and incentives, positive student attitudes and the engagement and support of both families and the local community. Samdal, Wold and Bronis (1999) also underscore a work-oriented environment and communication between teachers and students as important factors of school effectiveness.

Finally, it has been shown that schools are more effective when faculty reach a consensus regarding their vision, goals and values. This perspective is a basic foundation for creating a participatory school culture and a climate of collaboration (Hopkins, Ainscow, \& West, 1994; Murillo, 2007). Murillo (2008) defines it as a sense of community, the existence of shared goals and collegiality by teachers. Sammons, Hillman and Mortimore (1995) and Stoll and Fink (1999) underscore the importance of 
high-level leadership that fosters participatory management, so that all members of the educational community share the same vision, values and educational goals. A positive climate of participation gives rise to a climate of collaboration. Collaboration implies processes designed to render the educational community more open, and requires special attention be paid to relationships.

Among studies on school effectiveness in Latin America, the second regional study carried out by UNESCO/OREALC (2008) highlighted the importance of school climate as a key factor of effectiveness. To assess this factor, the authors propose the following indicators: the degree to which students feel comfortable and relaxed at school; their feeling of belonging to the institution; and their relationships with their fellow students. The Latin American model of school effectiveness (Murillo, 2007) includes climate at both a school and classroom level. At the level of the school, the following aspects are assessed: the existence of good relations between the different members of the school community; whether or not students feel happy, valued and supported by their teachers; and whether or not teachers and families feel satisfied. At the classroom level, the following aspects are taken into account: a positive and cordial atmosphere; affectionate relationships between teacher and students; and the absence of violence and conflicts to enable a better learning environment. School and classroom climates are closely related to each other, with a good working atmosphere in the school in general helping to foster a positive climate in the classroom. In another more recent study carried out in 248 classrooms in 9 Latin American countries, Murillo and Martínez-Garrido (2012) argue that climate should not only refer to good relationships between the members of the school community itself, but should also include another relevant factor, namely environmental conditions. The authors therefore conclude that environmental factors, such as tidiness and cleanliness in the classroom, impact the performance of students in year 3 of primary school. In another study on school climate, the same authors state that classroom climate is one of the factors which explains effective teaching (Murillo, Martínez-Garrido, \& Hernández-Castilla, 2011).

Closer to home, the study carried out in Spain with 24 primary and secondary schools is also worth mentioning (Muñoz-Repiso et al., 1995; Murillo, 1996). The authors found that school climate is a factor which influences all other variables, and is the best predictor of all three product variables (success rate, repetition rate and global satisfaction). It is measured as the quality of relationships both within and between different segments of the educational community and the faculty's sense of collegiality.

The conclusion drawn from the studies reviewed is that school climate is a multidimensional concept. Indeed, within the school effectiveness movement this concept has been studied from several different approaches, giving rise to disagreements regarding its definition and measurement.

One of the debates focuses on the difference between the constructs school culture and school climate. According to Schoen and Teddlie (2008), considerable overlap exists in the types of variables examined by school effectiveness researchers studying school climate, and more anthropologically oriented educational researchers studying school culture.

With the aim of clarifying this confusion, Van Houtte (2005) points out that school climate is based on the shared perception of behaviour in schools. It is an organisational characteristic that participants experience and which affects their behaviour. What distinguishes climate from culture is that climate is based on perception. School culture 
refers to shared assumptions, meanings and beliefs, whereas climate concerns the perception of those values, meanings and beliefs, as well as other relevant aspects of the total environmental quality of the organisation. Tagiuri (1968) also understands climate as a multidimensional concept that includes different aspects of the total environmental quality of an organisation. This author believes that climate also encompasses culture (beliefs, values, meanings, cognitive structures). Climate, therefore, refers to a broad concept that includes the characteristics that describe and distinguish an organisation. These characteristics are relatively long-lasting and influence the behaviour of those working within the organisation in question (Forehand \& Gilmer, 1964).

Schoen and Teddlie (2008), however, cite Schein's model (1985) and argue that school climate is actually part of school culture, which is defined at three levels (Artefactssymbols of culture; Espoused beliefs-school climate, and Basic assumptions-school culture).

The section below describes the education system in which this study on school effectiveness was carried out, with particular attention being paid to school climate.

\subsection{School climate in the context of the ARBC}

There is a regulation in the Basque Country regarding school climate, issued by the Basque Government Department of Education. Article 3 of the Basque Public School Act in 1993 includes the following aims among its stated objectives: a) To foster students' free development of personality and all-round education, based on values that enable peaceful and democratic coexistence; b) To encourage education for peace, freedom and the promotion of the ideas of cooperation and solidarity between peoples, and c) to ensure the co-educational nature of teaching.

Article 28 of the same Act refers to the autonomy that public non-university teaching institutions have in relation to approving and implementing the instruments that enable them to organise their activities. Thus, schools' Organisation and Operating Rules outline the regulations that guarantee peaceful coexistence and respect for rights, as well as ensuring that all members of the educational community fulfil their respective obligations. This enables schools to engage in actions designed to improve the climate of peaceful coexistence within their walls, and to take the necessary steps in response to situations of conflict.

There is also a decree on students' rights and obligations (Decree 201/2008) and a set of guidelines has been established for cases of bullying (Basque Government, 2011a). The aim is to make it easier to identify such cases and refer them to the intervention protocol. There is also a protocol for cases of cyberbullying, established by Del Rey and others (2011).

Another measure that has been taken is to oblige all schools to draft a Peaceful Coexistence Plan. Schools are provided with a set of guidelines with suggestions regarding possible areas of intervention: educational policy, organisation and management of everyday interactions; conflict transformation and ethics; emotions, feelings and identity; engagement; teaching and learning processes and teaching styles (Basque Government, 2011b). The aim of including these dimensions is to try and broaden schools' outlook and encourage them to implement preventive educational measures with students, as well as to strive to improve relationships between all members of the educational community (faculty, families, etc.). The objective is also to 
encourage improvements in management and organisation processes at a school-wide level. Schools are offered the opportunity of setting up a Peaceful Coexistence Observatory within their own premises, involving representatives from the whole educational community (families, faculty, non-teaching staff, etc.).

A substantial amount of research has been carried out in this context, focusing mainly on characterising abuse between peers (Ararteko, 2006; ISEI-IVEI, 2009, 2012). Nevertheless, one study of three particular cases analyses how peaceful coexistence is actively promoted in schools (Campo, Grisaleña, \& Fernández, 2004). The authors identify a number of primary strategies, including the fostering of positive relationships, the adoption of a preventive stance towards conflict and the involvement of the management team and project coordinators. Secondary strategies include the establishment of a clear set of rules of which the students are fully aware, encouraged participation of all involved and specific activities during class tutorials.

Nevertheless, no studies in this context have analysed the school climate of highly effective schools. The present study therefore aims to contribute to our body of knowledge regarding the best practices used by highly effective schools in relation to school climate. Its aim is to provide empirical evidence in relation to this topic, associated with the academic achievement of students in highly effective schools within the Basque Education System. The ultimate aim of this study is for the best practices identified to serve as a useful tool in the design and implementation of the improvement actions and programmes of all schools in the ARBC.

\section{Method}

A mixed model was followed, combining both quantitative and qualitative methods. Firstly, multi-level statistical modelling techniques were used to identify highly effective schools, whose students perform better than those of other schools operating in similar contexts. Secondly, qualitative methods were employed to characterise the best practices in these school.

\subsection{Quantitative analysis: Statistical analysis of the data and selection of the schools}

Since this was a census-based study, the sample comprised the whole school-going population attending state-funded schools in the ARBC, with 409 schools fitting this criterion in relation to year 4 of primary, and 324 schools fitting the criterion for year 2 of secondary. The total sample group comprised around 33,500 students in 2009, and 36,500 in 2010. Multilevel statistical modelling and Hierarchical Linear Models were used to select 32 highly effective schools. Of these, $50 \%$ were fully state-funded schools and the other $50 \%$ partially state-funded ones, including religious schools (18.75\%), Basque medium schools (12.5\%), teaching cooperatives (12.5\%) and others (6.25\%). The diversity of the schools was patent in relation to the SECI (socioeconomic and cultural index), the percentage of students from immigrant families, the percentage of those retaking the year and the percentage of SEN students, although the majority (53.1\%) scored in the mid-range in the SECI, had a $25 \%$ rate or lower of students from immigrant families $(87.5 \%)$ and students retaking the year $(75 \%)$, and reported a $2.5 \%$ to $5 \%$ rate of SEN students $(40.6 \%)$. 
The use of Multilevel statistical modelling and Hierarchical Linear Models ensures a more equal and better adjusted identification of schools, since it controls for the possible effects of contextual variables.

The statistical analyses were carried out on the basis of the results of the Diagnostic Assessments conducted in 2009 and 2010. Diagnostic Assessments (DAS) are tests designed ad hoc by the Basque Institute for Research and Evaluation in Education (ISEIIVEI) with the same aims as PISA (Programme for International Student Assessment). In specific terms, the results used were those obtained for Spanish language, Basque language and mathematics in 2009 and 2010, as well as those obtained for competence in the fields of culture, technology and health in 2009 and for social and citizenship skills in 2010. DAS are conducted on a census basis in all state-funded schools in the ARBC, and are strictly confidential. They are designed mainly for training and guidance purposes and have a twofold objective. Firstly, they aim to help schools internalise a culture of evaluation that fosters improvement processes, and secondly, they gather data on the characteristics of the schools themselves. This data is then used to help design more effective education policies.

Given the nested organisation of the data, the analyses were carried out from a multilevel perspective. The structure of the variability in each of the defined aggregation levels was respected, with the scores for each subject being nested at the student level (Level 1), which in turn is nested at the school level (Level 2). To adjust and validate the multilevel models, the decision was made to include only those variables that were strictly contextual (i.e. those over which the school has no influence).

Specifically, the $\mathrm{X}_{\mathrm{q}}$ Level 1 co-variables refer to students and indicate: a) the teaching language model chosen; b) sex; c) the language most used in the student's family; d) whether or not they themselves or one of their parents are immigrants; e) the family's economic, social and cultural status (ESCS); f) whether or not they are a retake student (i.e. whether or not they have been kept back a year); g) results obtained last year in the target competences; h) expectations regarding performance; i) whether or not they are given homework; j) number of hours spent doing homework; $k$ ) help received in relation to their homework; and 1) number of extracurricular activities engaged in throughout the week.

The linear equation of the multilevel model corresponding to this level, which encompasses the score variation in each criterion variable within each school is:

$$
y_{i j}=\beta_{0 j}+\sum_{q=1}^{Q} \beta_{q j} X_{q i j}+r_{i j}
$$

with $r_{i j} \sim N\left(0, \sigma^{2}\right)$, where:

$\mathrm{Y}_{\mathrm{ij}}$ : is the score obtained in each of the four competences assessed by student $i$ from school $j$.

$\beta_{0 \mathrm{j}}$ : is the mean performance of each school.

$\beta_{\mathrm{q} j}$ : is the linear influence of the student co-variable $\mathrm{X}_{\mathrm{q}}$

$\mathrm{X}_{\mathrm{qij}}$ : is the score obtained by student $i$ from school $j$ for the co-variable $\mathrm{X}_{\mathrm{q}}$ 
$\mathrm{r}_{\mathrm{ij}}$ : is the residual for student $i$ from school $j$, or in other words, the amount by which said student diverges from what is expected in their school.

As mentioned earlier, this differential or residual score was obtained using hierarchical linear modelling (HLM). A model was developed for each year and each school year, with the scores for each of the basic competences assessed in the DAS being incorporated as dependent variables and the contextual variables cited above which were found to be significant being included as estimators.

The general multilevel model (which, in the interests of simplicity, contains only one contextual estimator variable) is as follows:

$$
y_{i j}=\beta_{0}+\beta_{1} x_{i j}+\left(u_{1 j} x_{i j}+u_{0 j}+\varepsilon_{i j}\right)
$$

However, since in these models the slopes for the schools did not vary significantly from one year to another, the final model is as follows:

$$
y_{i j}=\beta_{0}+\beta_{1} x_{i j}+u_{0 j}+\varepsilon_{i j}
$$

Thus, the parameter $u_{0 j}$ is the residual for the school, and is the difference between the mean score obtained by the school and that estimated by the model, i.e. that obtained by other schools in similar contexts. For more detailed information about the statistical procedures used, see the work by Joaristi, Lizasoain, and Azpillaga (2014).

The co-variables corresponding to Level 2 (schools) were the percentages and, where appropriate, the means corresponding to the students at each school, divided into academic level and year. The following $\mathrm{W}_{\mathrm{s}}$ co-variables were considered: a) school network to which the school belongs; b) proportion of Basque-speaking students at the school (with Basque-speaking being understood as those who mainly speak Basque at home); c) proportion of immigrant students at the school; d) mean economic, social and cultural status of students at the school; e) proportion of retake students at the school; f) mean results obtained the previous year by students at the school; $\mathrm{g}$ ) proportion of students at the school who are given homework; h) mean number of hours spent by students at the school doing homework; i) mean amount of help received by students at the school in relation to their homework; j) mean number of extracurricular activities engaged in by students at the school throughout the week.

We based our analyses on the assumption that the influence of the Level 1 co-variables is the same in all schools. Thus, the structural model corresponding to each subject, which reflects the variation between schools, is:

$$
\beta_{0 j}=\gamma_{00}+\sum_{s=1}^{S} \gamma_{0 s} W_{s j}+u_{0 j}
$$

with the probabilistic part defined by $\mathrm{u}_{\mathrm{oj}} \sim \mathrm{N}\left(\mathrm{O}, \tau_{\mathrm{oo}}\right)$, where:

$\beta_{\mathrm{oj}}$ : is the mean performance for each school ( $)$,

$\gamma_{00}$ : is the effect common to all schools.

$\gamma_{0 s}$ : is the linear effect of the co-variable $\mathrm{W}_{\mathrm{s}}$ on the schools' mean performance.

$\mathrm{W}_{\mathrm{s} j}$ : is the value assumed by the school $j$ in the school co-variable $\mathrm{W}_{\mathrm{s}}$, 
$\mathrm{u}_{0 j}$ : is the residual variation between schools once all the individual and school factors included in the model have been controlled for.

Since $\mathrm{u}_{\mathrm{oj}}$ is the residual of school $j$ once the student and school effects have been controlled for, it was taken as the value by which each school deviated from what was expected of them. The selection of the schools was therefore based on this value. In short, two-level linear models were posed, obtaining as many equations as competences assessed and academic levels analysed.

Once the different models had been validated, the expected scores (residual) were calculated for each student and school. The selection procedure consisted of retaining only those schools in which a high mean residual (over the 80th percentile) was obtained for both academic years in all three basic competences or in two of them and in the mean for all four subjects measured.

The final result of this procedure was that 32 schools were selected. As regards their characteristics, $50 \%$ were fully state-funded schools and the other $50 \%$ partially statefunded ones, including religious schools (18.75\%), Basque medium schools (12.5\%), teaching cooperatives (12.5\%) and others (6.25\%). Of the total, $53.1 \%$ scored in the midrange for Economic, Social and Cultural Status.

\subsection{Qualitative analysis: Characterisation of the schools}

Three groups of key informants from the selected schools participated in the qualitative study: education inspectors, advisors from Training and Innovation Support centres and members of the management team. These informants were chosen because, firstly, the two first ones have extensive knowledge and an outside vision of the schools they advise about the dimensions studied in this research project; and secondly, the third group of informants complement this external view with an internal one, since members of the management teams are familiar with the internal working of their schools. Firstly, opinions were gathered from 25 inspectors from the Basque Government Education Inspectorate who had been assigned to these school (some to more than one of them). These inspectors ensure compliance with current laws and watch over the rights and obligations of those participating in school-based teaching and learning processes. Secondly, 26 advisors from the ARBC Training and Innovation Support centres were interviewed (these advisors were also those assigned to the schools studied). They offer advice on teaching issues, organise training sessions and work to promote innovation, experimentation and research in schools. And finally, the third group of participants comprised the 30 management teams from the 32 selected schools (two of the schools were represented in both educational stages, primary and secondary, and thus had the same management team).

Three instruments were developed for the three key informant groups. The aim was to obtain the most detailed information possible, bearing in mind the specialist expertise of each informant group.

With respect to procedure, the tasks involved in the qualitative phase were: a) review of the literature and formulation of an initial set of categories; b) study and selection of informants; c) design of the instruments and establishment of a protocol; and d) holding of the interviews from January to May 2012. Each sequence of the transcriptions of the 83 interviews held was assigned to one of the analysis categories. The global analysis categories for the project were: 1) projects, plans and training; 2) teaching 
methodologies and materials; 3) attention to diversity; 4) student follow-up, individual attention, guidance and tutorials; 5) student assessment; 6) time management; 7) leadership and the management team; 8) management and organisation models; 9) coordination; 10) engagement and sense of belonging; 11) teacher assessment, school assessment, assessment of programmes and activities and use of the Diagnostic Assessment; 12) school climate; 13) image, facilities and resources; 14) family, community and social capital.

Next, an initial schema of second-order sub-categories was developed. These subcategories were considered possible best practices for the thematic area in question. The information obtained in the school climate category forms the basis of this present paper. As indicated above, there are different approaches to school climate within the school effectiveness movement. We restrict our focus to the sub-categories of school climate featured and explained below (table 1): 1. Academic climate; 2. Social climate; 3. Organisational structures.

Although these aspects can be explored through different stakeholders, in this study they were analysed on the basis of statements made by the inspectorate, educational advisors and management teams. As You, O'Malley and Furlong (2014) point out, perceptions of climate among different groups of workers within the school environment have received very little attention.

Table 1. Schema of sub-categories

\begin{tabular}{ll}
\hline \multicolumn{1}{c}{ SUB-CATEGORIES } & \multicolumn{1}{c}{ COMPONENTS } \\
\hline \multirow{2}{*}{ Academic climate } & $\begin{array}{l}\text { Conditions that facilitate learning } \\
\text { Clear rules and responses to indiscipline. }\end{array}$ \\
\hline \multirow{2}{*}{ Social climate } & $\begin{array}{l}\text { Measures to protect and support teachers, and to aid initial } \\
\text { adaptation. } \\
\text { Social relations between all members of staff. }\end{array}$ \\
\hline \multirow{2}{*}{ Organisational structures } & $\begin{array}{l}\text { Consensus among faculty regarding vision, feeling of } \\
\text { belonging and engagement. } \\
\text { Participatory management and collegiality. }\end{array}$ \\
\hline
\end{tabular}

Source: Compiled by the authors.

\section{Results}

In general, informants considered climate to be a relevant factor for the efficient running of their school. In their statements, they underscored the importance of: 1) A good academic conditions that facilitate learning; 2) a positive social climate among the members of the educational community; 3) consensus regarding vision, a feeling of belonging and participatory management which results in more fluent, open communications between all those at the school.

\subsection{Academic climate}

Respondents stated that, for them, academic climate referred to students feeling good at school in relation to their learning process. The main aim in this sense is all-round education, which involves planning preventive programmes focused on areas such as emotion management, social skills and values, among others. Informants also believe that academic climate encompasses discipline and the enforcement of rules that aim to correct behaviour not conducive to positive and harmonious coexistence. 


\title{
3.1.1. Conditions that facilitate learning
}

Informants stated that to their minds, the concept of education was related to students' all-round development (intellectual, emotional and social). They reiterated the importance of teaching values as a necessary condition for ensuring a positive learning environment.

\begin{abstract}
Our educational objective is to ensure that students are as fully developed as possible; we aim to instil in them a sense of their own worth and to offer them all the opportunities they may not have in their social environment. (...) The climate generated is good, and a lot of emphasis is placed on values. (Management team, School 35068)

Offering a high-quality educational service means that by the time your child finishes his or her time with us they will have acquired a sound academic grounding. They will also have imbued a set of agreed-upon values, and here we demand commitment from them too (...) Social integration and emotional intelligence are also important. These are aspects that have traditionally been overlooked in schools, but here we are committed to researching and working on them. (Management team, School 30602)
\end{abstract}

One of the most common measures taken to foster all-round student development are prevention programmes. These can take the form of tutorial action through the tutorial plan, or can be implemented in the form of projects related to values education, such as the pentacidad project (an educational project structured around five areas: identity, social skills, the mind, the body and emotions, which aims to foster the all-round development of capacities and values), conflict resolution, pastoral care activities and a special corner for reaching agreements called ados txokoak.

There are special corners in the classroom for working on peaceful coexistence within the framework of the pentacidad project. Students understand the process for working within the project and know what to do in the event of a conflict. All this is clearly reflected in the atmosphere. (Inspectorate, School 37092)

The school is very clear about the fact that tutorial work is the best way of resolving. discipline problems. (Management team, School 37532)

\subsubsection{Clear rules and responses to indiscipline}

Informants refer to the need to respond to situations of conflict as a prerequisite for satisfactory academic development. It should be noted that none of the participating schools reported cases of serious conflict within the school environment, and only one case of peer bullying was mentioned. In this case, an attempt was made not to view and deal with the problem as an issue affecting the entire school, but rather to resolve it with the teachers, family and corresponding member of the inspectorate.

Faculty are alert to possible warning signs, and always try to resolve the problem early, before it has time to develop. Each situation is dealt with by trying to find solutions, striving to diffuse rather than fuel the conflict. Problems are first dealt with in the school itself, by talking to those involved and the corresponding tutor; only when this fails do the management team and/or families get involved. Educational measures are more common than restrictive ones involving punishments and expulsion, etc.

They are not advocates of disciplinary proceedings as established in the decree; they prefer other methods. (Inspectorate, School 31746)

Of course, there are conflicts, but they deal with them quickly and have a good protocol for taking action. (Inspectorate, School 36124) 
To enforce their rules of peaceful coexistence, the schools studied make use of two documents with clear, unified protocols for action: The Peaceful Coexistence Plan and the Organisation and Operation Rules (OOR).

A well-designed Peaceful Coexistence Plan is seen as vital for reaching agreements between the different members of the educational community (parents-students-faculty). A knowledge of the rules of peaceful coexistence by students, families, faculty and nonteaching staff helps prevent possible problems.

\section{Secondary school teachers, students, parents and staff are all working together to ensure peaceful coexistence and a good climate. Teamwork is extremely important. (Management team, School 37202) \\ They drafted an OOR and established a Peaceful Coexistence Plan. It's important to involve teachers and the educational community in general - including parents. (Inspectorate, School 33462)}

Respondents expressly referred to the usefulness of the peaceful coexistence plan for avoiding risks in situations of conflict. The plan serves as a basic reference for standardising the rules of peaceful coexistence within a school environment.

One best practice identified in the schools studied is the taking of specific measures to foster a feeling of safety. The majority of schools focus preventive measures on break times and play areas. These measures include teachers being on playground duty and the organisation of recreational activities during break times that seek to foster student inclusion and improve peaceful coexistence. Finally, a few schools appoint break time mediators from among the student body. These students receive training in conflict management and assume responsibility for mediating any possible conflicts that may arise among their fellow pupils.

There is very little conflict. They believe having teachers on duty during break times is important, as is the organization of structured activities during these periods. Activities are organized by the PE staff, and count as teaching hours for them. (Management team, School 31746)

To monitor the implementation of the peaceful coexistence plan, some school have set up a peaceful coexistence observatory made up by teachers, students, parents and, in some cases, non-teaching staff also (canteen workers, for example).

They have a very strong peaceful coexistence committee that tackles conflicts early on and provides important support when conflictive situations arise. (Inspectorate, School 33462)

Every year has a democratically-elected delegate; there's also a school bus delegate and a canteen delegate, etc. They meet once a fortnight to talk over any conflicts and discuss possible solutions. The principal takes the minutes, which are then read out by tutors in their classrooms. (Management team, School 27802)

Finally, another preventive measure identified was teacher training, particularly in the field of mediation and conflict resolution.

Training in conflict resolution is vital, and is assessed very positively by teachers. And they are carrying on with these plans... (Advisor, School 28798) 


\subsection{Social climate}

\subsubsection{Protection and support for teachers, and steps to aid initial adaptation}

The management team believes it is important to respond to teachers' requests for protection. Thus, the management teams at some schools provide specific support to teachers in difficult situations. The aim is to make them feel safe, and to facilitate problem resolution.

We are like an umbrella for the faculty. We make a real effort to ensure that teachers feel supported (...) we strive always to protect, respond, provide continuity and, above all, to help resolve problems. (Management team, School 31746)

Another indication of support provided by the management team is the participation of one or more of its members in the projects/committees carried out/set up in the school.

We believe teachers are more likely to get involved in a project if there is clear support from the management team. (Management team, School 30976)

Another best practice is ensuring good working conditions for teachers (timetables, family-work life balance, etc.), although a certain contradiction was detected in this sense. The idea of not overloading teachers exists side by side with a demand for commitment and performance, which in many cases results in them dedicating more time to the school than the hours established in their contracts. This is particularly true in the case of semi-private schools (i.e., private schools that receive some state funding).

We want teachers to feel good and not stressed out and overworked; they need to have time for their personal lives. (Management team, School 35068)

In relation to teachers, when drawing up the timetables they are allowed to make suggestions and we try to accommodate them whenever we can. Personal issues are always taken into account as far as possible. (Management team, School 35662)

Recognition of teachers' work by the management team is also an important source of motivation. Another best practice identified in many schools was the management team's effort to forge a cohesive group despite different approaches and outlooks.

\section{It is clear when a management team makes an effort to foster a good atmosphere. There are no major ideological disputes; even through everyone is very different. (Management team, School 29986) \\ The atmosphere is pleasant. There is a feeling of belonging to a single group, a single school. (Management team, School 29612)}

The statements made by the external figures (advisors and members of the inspectorate) indicate that faculty appreciate the involvement and commitment of the management team and its leadership in creating a climate of trust and communication.

Teachers who appreciate the effort made by the management team get more involved in the organization, as well as in the training sessions led by the management. (Advisor, School 31768)

The principal is the heart and soul of the school. She is a clear authority figure with a set of firm educational and value-based goals that she conveys to the faculty, and the faculty share those goals. (Inspectorate, School 33462)

The majority of schools have a set of internal operating guidelines and an orientation protocol for new teachers, supply teachers or trainee teachers, as well as for students. A specific person is appointed to help orient the new member of staff, and other strategies are also used to help facilitate their integration into the school. By way of example, we 
can highlight the criterion that new teachers are spread over different key stages, as well as the decision not to assign them particularly difficult tasks.

When we hire a new teacher, we tell them what kind of school this is and explain what is expected from teachers working here. They are given a copy of the teacher functions manual. They are also assigned a tutor from among the existing faculty. (Management team, School 35662)

Whenever new teachers join the school we try to assign them to different key stages. That's an official, established criterion. There's always an experienced teacher at every level. (Management team, School 37950)

\subsubsection{Social relations between all members of staff}

The management teams of some schools are aware that academic relationships are enhanced and strengthened by good social relations. To this end, they strive to organise activities that foster interaction in a purely informal atmosphere. This promotes better communication and verbal interaction for all involved.

They have a special place, the staff room, in which they can get together. And they also have time set aside for this: every Friday plus the last day before the holidays. (Management team, School 31768)

The coffee morning is when the primary school teachers - mainly - get together to have a chat. It's a moment of ongoing coordination. (Management team, School 29612)

I believe in the hidden curriculum, I try hard to promote and improve it (referring to organizing lunches, outings and celebrations for the teaching staff). (Management team, School 27082)

In addition to relations between teachers at the school, the relationship with administrative and other non-teaching staff is also taken into account in an attempt to ensure everyone's involvement and commitment. This community-wide engagement is an aspect that is reflected, as mentioned earlier, in the schools' Peaceful Coexistence Plans.

All practices are designed to foster an agreeable, motivating academic and social environment that fosters consensus regarding goals and values.

\subsection{Organisational structures}

A number of best practices for fostering a good climate were identified in the study. One of these was forging a consensus regarding the school's vision, a sense of belonging, faculty engagement and participatory management and collegiality.

\subsubsection{Consensus regarding vision, feeling of belonging, and faculty engagement}

In the majority of the schools studied, teachers were described as sharing the school's identity and ideology. They feel a sense of ownership in relation to the school and have a sense of being "one large family". They identify with and believe in what the school is trying to achieve and feel happy to be part of the effort. Teachers are seen as committed professionals who engage with their students and are sensitive to their specific requirements. Hence their concern about responding to students' needs outside the strictly academic sphere, even when this involves a large amount of time and effort.

The source of their feeling of belonging to the school lies in their sharing of the school's aims and goals. (Management team, School 30976) 
Here we get stuck into whatever comes our way. There are people here who are always willing to jump right in. (Management team, School 37202)

A fair degree of diversity was detected in relation to school identity. Some schools have a more family-oriented tradition, with many teachers being ex-students themselves. This generates a strong feeling of familiarity and results in a high level of identification with the school. Other schools have a more religious identity, which generates a sense of moral responsibility to provide a service to students from a socially disadvantaged background.

There are also cases of schools with a strong cultural identity, mainly as a result of the bilingual situation of the Basque Country. These schools make a firm commitment to fostering the minority language spoken in the region (Basque), and their educational processes are aimed at promoting an appreciation of the language among students. Some schools are cooperatives, with teachers also being owners and shouldering the responsibility for developing the long-term educational initiative. In some public schools the management team is firmly committed to the public function of education. In other words, they are firmly in favour of fostering inclusion by encouraging students to learn the different languages spoken in their country.

These strong links with the school's goals and projects lead to a greater feeling of belonging among teachers, and more active engagement. It was also observed that this in turn is partly reinforced by the presence of a stable group of teachers who have been at the school for years and are eager to instil this feeling of identity in new members of staff.

Those who have been here for years feel that the school is theirs and we feel happy to be part of it. (Management team, School 32252)

There is a stable team of teachers who have made a real effort to make this work; and not just that - they also strive to convey the philosophy of what we do here and how we do it to everyone new who joins us. This doesn't always happen in every school (...). (Management team, School 31746)

In juxtaposition, some informants felt that the teachers were not actively engaged with the school. Nevertheless, in these cases, the management teams said they felt satisfied because students come to school happily.

\subsubsection{Participatory management and collegiality}

Much emphasis was placed on the importance of fostering a sense of ownership, and of establishing more horizontal organisational structures. According to informants, the majority of the schools studied stand out due to their democratic decision-making processes. They take teachers' needs and ideas into account when implementing improvements. In this sense, a good two-way channel of communications is of inestimable help (management-teachers/teachers-management).

It's the team's job to foster horizontal, group-oriented approaches in order to ensure true teamwork and a greater degree of teacher engagement in the school. (Management team, School 37532)

Representatives of the educational team and key stage coordinators are present in the management team. There is fluent communication between the management and teachers. (Advisor, School 32252)

By way of example, it is worth pointing out that $23 \%$ of schools have a cooperative organisation model, which means that the staff and/or families can also be owners. This 
cooperative structure facilitates the involvement of both teachers and families in the decision-making process. It was also observed that in some of the schools studied, special bodies are set up to encourage greater faculty participation.

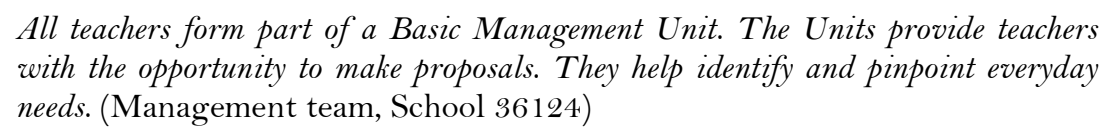

Moreover, $37 \%$ of the schools studied have implemented a quality system which organises the school around groups of processes defined on the basis of a series of key axes. Each process is assigned a leader from among the teaching staff, a system which promotes a more even distribution of responsibilities.

\begin{abstract}
We are committed to participatory management, within the EFQM management system, so we definitely believe in a more horizontal than vertical organization scheme. There has been a change of mindset. There is now a management team that takes strategic actions into account, but also strives to foster participation. (Management team, School 35668)
\end{abstract}

Another aspect worth highlighting is that teachers are clear about what tasks are assigned to them and tend to perform them.

Since the staff is fairly stable, the distribution of responsibilities is also stable. All teachers are involved in one group or another. They all have responsibilities. (Inspectorate, School 30976)

\title{
4. Discussion
}

This study provides greater insight into the educational practices of highly effective schools in the Autonomous Region of the Basque Country. In general, informants described a good school climate as regards school-related aspects (faculty cooperation, good relations between students, good organisation and management, etc.). This best practice helps improve our understanding of what makes a school highly effective and provides guidelines for improvement that are consistent with the findings reported by other authors (Sammons, Hilman, \& Mortimore, 1995; Scheerens et al., 2013).

\subsection{Academic climate}

In order to enable good learning, the schools analysed in our study believe it is vital to create an adequate climate in which students feel safe, both emotionally and socially. In this sense, respondents emphasise the importance of a firm commitment to all-round education.

A common strategy is educational intervention focused on prevention. A number of classroom-based methods were mentioned, such as tutorial plans and programmes for teaching values. These findings are similar to those reported in other studies, such as the one by Murillo and Hernández-Castilla (2011), which highlights the use of participatory methods and attention to diversity as factors that help generate a good climate in the classroom, thus fostering a higher level of teacher satisfaction.

Peaceful, conflict-free coexistence is one striking best practice identified in these schools. In contrast to the situation of social alarm reported by the media, these schools do not profess themselves to be overly concerned about the existence of school violence or bullying, and indeed only one case of the latter was mentioned. 
As a recourse in the case of and strategic response to possible situations of conflict, in addition to a general prevention plan, schools also reported having clear, unified protocols such as a school-wide Peaceful Coexistence Plan and a set of Organisation and Operating Rules. The peaceful coexistence plan is seen as a useful tool for standardising behaviour in this field. However, preventive strategies were also identified in other areas of the school, particularly in the playground and other recreational areas.

Effective practices include a timetable for playground duty, the organisation of activities designed to foster inclusion among students and the appointing of specially-trained mediators from among the student body to mediate any conflicts that may arise. These are all measures that are outlined in article 48 of the Decree (2008) on Students' Rights and Obligations. Torrego and Moreno (2003) classify peaceful coexistence models into three types: punitive, relational and integrated. The schools studied here fall into the integrated category, which includes a set of democratically-established rules and an attitude to conflict resolution characterised by dialogue, mutual understanding, consensus and agreement.

Another best practice identified was teacher training and the participation of teaching staff in the design and monitoring of the peaceful coexistence plan, with the agreement of all members of the school community, such as families and non-teaching staff (canteen workers, those responsible for extracurricular activities and the school bus service, administrative staff, etc.), through the committee and/or peaceful coexistence observatory.

Nevertheless, there are still areas of the school, such as the corridors and toilets, for example, which are more invisible and unmonitored than others. It is these areas that may become the focal points for conflict, since students there are more vulnerable. Possible cases of cyberbullying, which is becoming more and more common, should also be taken into account.

\subsection{Social climate}

As reported in the study by Murillo and Hernández-Castilla (2011), the highly effective schools studied here generate a positive climate, and the management teams make a concerted effort to create a motivating work atmosphere. The management teams engage in effective practices, including: a) protecting and providing teaching staff with a sense of safety when faced with difficult situations (discipline problems among students, complaints from families); b) engagement of the management team in projects or the various committees; c) ensuring good working conditions; and d) striving to generate a sense of cohesion in the event of possible differences of opinion and outlook. Arnaiz (2012) argues that for a school to function well, what is required is a set of working conditions characterised by collaboration and acknowledgment of the contribution made by all members of staff.

Our study found that teachers greatly appreciate their management teams and their level of engagement. The feeling of mutual support evinced between the teaching staff and the management team indicates that these schools have developed a culture of mutual care, with special attention being paid to new teachers. This helps generate an interactive relationship between the different members of the school organisation (management team, teachers, students and families). 
Another important aspect to bear in mind is that social climate complements academic climate. Hence, the management teams interviewed in our study make a conscious effort to foster social relations (organising events and celebrations, etc.).

\subsection{Organisational structures}

The characteristics of the schools studied are fairly diverse. As a result, each school has its own identity (religious, cooperative, cultural, public, etc.) and has reached its own consensus regarding its vision. Teachers identify with and internalise their school's ideology. This in turn helps to foster engagement and commitment. One thing highlighted during the interviews was the importance of having a stable team of teachers to help develop the school's identity and generate a good climate. This helps foster a feeling of belonging and a greater degree of engagement, especially among new teachers. As Hernández and Sancho (2004) point out, continuity of teaching staff in a school is an indication of good collaboration, which in turn fosters a greater degree of involvement in educational projects by teachers.

An atmosphere of trust and communication in favour of collaborative work is expressed in the form of teamwork and participatory management. The general trend detected is towards finding common ground by promoting communication and prioritising democratic-style leadership. New, more horizontal organisational structures were also identified, which are designed to stimulate faculty participation in the school's organisational dynamics. Examples include cooperative schools and quality systems that encourage process-based teamwork.

\section{Conclusion}

To conclude, we should highlight the important role played by a positive climate in improvement processes. As Martin (2000) states, working climate or atmosphere is not just a factor that facilitates organisational or management processes, it also fosters innovation and change. Fullan (1982) states that the quality of professional relationships is closely related to the implementation of school development programmes.

The purpose of this study was to help gain a better understanding of how to improve effectiveness. The aim is to orient change and offer proven improvement methods that can be incorporated into the improvement plans that the Basque education policy requires all schools in the region to development. Thus, a connection can be forged between school effectiveness and school improvement.

The following are the contributions made by this study: a) we suggest that preventive measures be deployed at a school-wide level in order to foster an adequate learning climate; this should be done by creating and maintaining the school climate as a learning objective (Tutorial Action Plan, Peaceful Coexistence Plan and other values education programmes); b) we suggest that both inspectors and advisors strive to monitor the design, implementation and assessment of the Tutorial Action Plans and the Peaceful Coexistence Plans designed by schools in order to ensure the inclusion of school climate as a learning objective at all levels (students, teachers, non-teaching staff, families). This implies the specification and implementation of conditions and processes for ensuring positive interactions, fostering teamwork and promoting the democratic participation of students, professionals and families; $\mathrm{c}$ ) we suggest that activities designed to consolidate group relations be included in student and educator training programmes, along with 
activities designed to foster commitment and facilitate contact between people, affective integration and an appreciation of our mutual interdependence. All this will foster a view of climate which goes beyond peaceful coexistence between students, which is often seen solely in terms of conflict; d) we suggest that schools plan the following aspects at both a classroom and organisational level: the integration of everyone into education actions, the acceptance of existing differences and the inclusion of new students and teachers into the school community, the provision of an environment in which teachers feel protected and valued, and the design of celebratory activities and social, recreational events; and finally, e) we suggest that schools strive to enact policies that ensure stable professional teams which help foster a school identity and promote new, more horizontal organisational structures that stimulate participation and teamwork.

The study has a number of limitations, one of which is the fact that neither teachers, students nor their families participated in the study. This makes it difficult to obtain data on those aspects more closely linked to the classroom environment and to verify the data gathered in relation to school climate. Another means of obtaining more conclusive results would be to compare the practices identified in highly effective schools with those in place in schools with a very low residual (added value), in order to avoid erroneous conclusions owing to the lack of this information (although these aspects are currently being worked on). Future research should consider the use of other techniques, such as direct observation, in order to complement the information gathered and gain a more holistic view of the characteristics of each school.

\section{Funding}

This work was supported by the General-Directorate for Research and Management of the National R\&D\&I Plan, as part of the National Basic Research Project Programme within the framework of the 6th National Scientific Research, Development and Technological Innovation Plan 2008-2011 under reference [EDU2011-24366] as part of the project entitled 'Characterisation and best practices in high added value schools' directed by Luis Lizasoain Hernández. The project has continuity under the project entitled "Longitudinal and contextualized study of schools with very high and very low seffectiveness: School improvement programs design" directed by Luis Lizasoain Hernández and supported by General-Directorate of Scientific and Technical Research, National Programme for fostering excellence in Scientific and Technical Research, National Sub-Programme for Knowledge Generation, under reference [EDU201453511]. This work is also supported by the group of UPV/EHU (GIU15/14) entitled Gender socialization and educational contexts.

\section{References}

Ararteko. (2006). Bizikidetza eta gatazkak ikastetxean [Peaceful coexistence and conflict in schools]. Vitoria: Ararteko.

Arnaiz, P. (2012). Escuelas eficaces e inclusivas: Cómo favorecer su desarrollo. Educación XXI, $30(1), 25-44$.

Basque Government. (2011a). La guía de actuación en los centros educativos ante el maltrato entre iguales. Vitoria: Gobierno Vasco. 
Basque Government. (2011b). Guía para el plan anual de la convivencia. Vitoria: Gobierno Vasco.

Brookover, W. B., Beady, C., Flood, P., Schweitzer, J., \& Wisenbaker, J. (1979). School social systems and students achievement. New York, NY: Praeger.

Campo, A., Grisaleña, J., \& Fernández, A. (2004). Bizikidetasuna bigarren hezkuntzako ikastetxeetan: Kasuak aztertzea [Summary: Living together in secundary schools: A case study]. Bilbao: ISEI-IVEI

Creemers, B. P. M. (1994). The effective classroom. London: Cassell.

Del Rey, R., Flores, J., Garmendia, M., Martínez, G., Ortega, R., \& Tejerina, O. (2011). Protocolo de actuación escolar ante el ciberbullying. Vitoria: Gobierno Vasco.

Edmonds, R. (1979). Effective schools for the urban poor. Educational Leadership, 37(1),15-24.

Forehand, G., \& Gilmer, B. (1964). Environmental variation in studies of organizational behavior. Psychologival Bulletin, 62, 361-382. https://doi.org/10.1037/h0045960

Fullan, M. (1982). The meaning of educational change. Boston, MA: Teacher College Press.

Gray, J. (2006). La eficacia escolar y otros resultados de la Enseñanza Secundaria: Una evaluación de tres décadas de investigación británica. REICE. Revista Iberoamericana sobre Calidad, Eficacia y Cambio en Educación, 4(1),16-28.

Hernández, F., \& Sancho, J. M. (2004). El clima escolar en los centros de secundaria: más allá de los tópicos. Madrid: Ministerio de educación y ciencia. Madrid: C.I.D.E.

Hernández-Castilla, R., Murillo, F. J., \& Martínez-Garrido, C. (2014). Factores de ineficacia escolar. REICE. Revista Iberoamericana sobre Calidad, Eficacia y Cambio en Educación, 12(1), 103-118.

Hopkins, D., Ainscow, M., \& West, M. (1994). School improvement in an era of change. London: Cassell.

ISEI-IVEI. (2009). El maltrato entre iguales en Euskadi. Bilbao: Gobierno Vasco.

ISEI-IVEI. (2012). El maltrato entre iguales en Educación Primaria y ESO. Bilbao: Gobierno Vasco.

Joaristi, L., Lizasoain, L., \& Azpillaga, V. (2014). Detección y caracterización de los centros escolares de alta eficacia de la comunidad autónoma del País Vasco mediante modelos transversales contextualizados y modelos jerárquicos Lineales. Estudios Sobre Educación, 27, 37-61. https://doi.org/10.15581/004.27.37-61

Lizasoain L, Intxausti, N., \& Azpillaga, V. (2012, april). Detección, caracterización y buenas prácticas de centros escolares de alto valor añadido de la comunidad autónoma vasca. Paper presented to the $X V$ National Congress and $V$ Ibero-American of Pedagogy. Burgos.

Martin, M. (2000). Clima de trabajo y organizaciones que aprenden. Educar, 27, 103-117.

Muñoz-Repiso, M., Cerdán, J., Murillo, F. J., Calzón, J., Castro, M., Egido, I., García, R., \& LucioVillegas, M. (1995). Calidad de la educación y eficacia de la escuela. Estudio sobre la gestión de los recursos educativos. Madrid: CIDE.

Murillo, F. J. (1996). ¿Son eficaces nuestras escuelas? Cuadernos de Pedagogía, 246, 66-72.

Murillo, F. J. (2007). Investigación iberoamericana sobre eficacia escolar. Bogotá: Convenio Andrés Bello.

Murillo, F. J. (2008). Hacia un modelo de eficacia escolar. Estudio multinivel sobre los factores de eficacia de las escuelas españolas. REICE. Revista Iberoamericana sobre Calidad, Eficacia y Cambio en Educación, 6(1), 4-28. 
Murillo, F. J., \& Hernández-Castilla, R. (2011). Factores escolares asociados al desarrollo socioafectivo en Iberoamérica. RELIEVE, 17(2), 1-18.

Murillo, F. J., \& Martínez-Garrido, C. (2012). Las condiciones ambientales en las aulas de primaria en Iberoamérica y su relación con el desempeño académico. Archivos Analíticos de Políticas Educativas, 20(18), 1-24.

Murillo, F. J., Martínez-Garrido, C., \& Hernández-Castilla, R. (2011). Decálogo para una enseñanza eficaz. REICE. Revista Iberoamericana sobre Calidad, Eficacia y Cambio en Educación, 9(1), 6-27.

Purkey, S. C., \& Smith, M. S. (1983). Effective schools: A review. Elementary School Journal, 4, 427-452. https://doi.org/10.1086/461325

Reynolds, D., Creemers, B., Stringfield, S., Teddlie, C., \& Schaffer, G. (2005). World class schools: International perspectives on school effectiveness. London: Routledge.

Rutter, M., Mortimore, P., Ouston, J., \& Maughan, B. (1979). Fifteen thousand hours. London: Open Books.

Sammons, P., Hillman, J., \& Mortimore, P. (1995). Key characteristics of effective schools: A review of school effectiveness research. London: OFSTED.

Samdal, O., Wold, B., \& Bronis, M. (1999). Relationship between student's perception of school environment, their satisfaction with school and perceived academic achievement: An international study. School Effectiveness and School Improvement, 10(3), 296-320. https://doi.org/10.1076/sesi.10.3.296.3502

Scheerens, J. (1990). School effectiveness research and the development of process indicators of school functioning. School Effectiveness and School Improvement, 1(1), 61-80. https://doi.org/10.1080/0924345900010106

Scheerens, J. (1992). Effective schooling: Research, theory and practice. London: Cassell.

Scheerens, J., \& Bosker, R.J. (1997). The foundations of educational effectiveness. Oxford: Pergamon.

Scheerens, J., Witziers, B., \& Steen, R. (2013). A meta-analysis of school effectiveness studies. Revista de Educación, 361, 619-645. https://doi.org/10.4438/1988-592X-RE-2013-361235

Schoen, L. T., \& Teddlie, C. (2008). A new model of school culture: A response to a call for conceptual clarity. School Effectiveness and School Improvement, 19(2), 129-153. https://doi.org/10.1080/09243450802095278

Stoll, L., \& Fink, D. (1999). Para cambiar nuestras escuelas. Reunir la eficacia y la mejora. Barcelona: Octaedro.

Stringfield, S., \& Slavin, R. E. (1992). A hierarchical longitudinal model for elementary school effects. In B. P. M. Creemers, \& G. J. Reezigt (Eds.), Evaluation of educational research (pp. 35-69). Groningen: ICO.

Tagiuri, R. (1968). The concept of organizational climate. In R. Tagiuri \& G. H. Litwin (Eds.), Organizational climate: Exploration of a concept (pp 11-34). Boston, MA: Harvard Bussiness Administration.

Torrego, J. C., \& Moreno, J. M. (2003). Convivencia y disciplina en la escuela. El aprendizaje de la Democracia. Madrid: Alianza.

Townsend, T. (2007). International handbook of school effectiveness and improvement. Dordrecht: Springer. https://doi.org/10.1007/978-1-4020-5747-2 
UNESCO/OREALC. (2008). Los aprendizajes de los estudiantes de América Latina y el Caribe. Primer reporte de los resultados del SERCE-Segundo Estudio Regional Comparativo y Explicativo. Santiago de Chile: OREALC/UNESCO.

Van Houtte, M. (2005). Climate or culture? A plea for conceptual clarity in school effectiveness research. School Effectiveness and School Improvement, 16(1), 71-89. https://doi.org/10.1080/09243450500113977

Weber, G. (1971). Inner-city children can be taught to read: Four successful schools. Washington, DC: Council for Basic Education.

You, S., O'Malley, M. D., \& Furlong, M. (2014). Preliminary development of the brief-California school climate survey: Dimensionality and measurement invariance across teachers and administrators. School Effectiveness and School Improvement, 25(1), 153-173. https://doi.org/10.1080/09243453.2013.784199

\section{Brief CV of the authors}

\section{Feli Etxeberria}

Professor, honorary collaborator at the University of the Basque Country. His trajectory of research and teaching is related to education. Emphasize the lines of bilingualism, plurilingualism, language pedagogy, attention to diversity, gender and new socializations, the immigrant family from the educational perspective and improvement of efficiency in schools. Participation in research projects of national and international character, to indicate the European Projects from 1992 to 2000. Direction of several doctoral theses and masters (1992-2006). Numerous publications in magazines and books. Direction of Congresses and participation as guest. It has six years of research (CNEAI). Management experience as secretary of the Faculty FICE (UPV) and direction of the Department MIDE (UPV). He belongs to scientific societies, and is a member of Committees. ORCID ID: 0000-0001-6059-796X. Email: feli.etxeberria@ehu.eus

\section{Nahia Intxausti}

Lecturer at University of the Basque Country. The author's research and teaching trajectory is mainly associated to the study areas of attention to diversity and inclusive education, the family-school relationship in contexts of diversity, and to the improvement of school effectiveness. In this last area, she has focused his study on the aspects of coexistence, climate, diversity and leadership. He has participated in university and national research projects. ORCID ID: 0000-0002-8210-334X. Email: nahia.intxausti@ehu.eus

\section{Verónica Azpillaga}

Lecturer at University of the Basque Country, Department of Methods of Research and Diagnosis in Education. She has worked the lines of Pedagogy of Language and Educational Orientation. She teaches teaching about the communicative interaction and communicative styles of teachers. It develops the second R \& D project on School Efficiency in the Basque Autonomous Community and participates in the Gender Socialization Research Group. ORCID ID: 0000-0001-6949-7041. Email: veronica.azpillaga@ehu.eus 